\title{
Combination of Salinity and Sodicity Levels Facilitates Screening of Medicinal Crop Linseed (Linum Usitatissium)
}

\author{
Muhammad Arshad Ullah ${ }^{1 *}$, Muhammad Rasheed ${ }^{2}$ and Imdad Ali Mahmood ${ }^{1}$ \\ ${ }^{1}$ Land Resources Research Institute, National Agricultural Research Centre, Pakistan
}

${ }^{2}$ PMAS - Agronomy Department, University of Arid Agriculture, Pakistan

Received: 㭗: October 03, 2018; Published: 制: October 29, 2018

*Corresponding author: Muhammad Arshad Ullah, Land Resources Research Institute, National Agricultural Research Centre, Pakistan

\begin{abstract}
Salts lessen germination, delay emergence, and retard seedling growth of linseed (Linum Usitatissimum L.). In this research experiment, we designed to find out the effects of $(4 \mathrm{dSm}-1+13.5$ (mmol L-1)1/2, $5 \mathrm{dSm}-1+25$ (mmol L-1)1/2 , $5 \mathrm{dSm}-1+30$ (mmol L-1)1/2, $10 \mathrm{dSm}-1$ + 25 (mmol L-1)1/2 and $10 \mathrm{dSm}-1+30(\mathrm{mmol} \mathrm{L}-1) 1 / 2)$ on biomass yield of linseed to screen against salinity tolerance using biomass yield characteristic. Highest biomass yield (45.53 gpot- 1 ) was attained by $4 \mathrm{dSm}-1+13.5$ (mmol L-1) $1 / 2$ treatment. Biomass yield was decreased as well as the toxicity of salts was increased. Lowest biomass yield (27.75 gpot-1) was produced at $10 \mathrm{dSm}-1+30(\mathrm{mmol} \mathrm{L}-1) 1 / 2.5 \mathrm{dSm}-1+25$ (mmol L-1)1/2 treatment performed better results i.e. the least reduction \% over control (20.25). Salinity- sodicity showed serious effect on the growth reduction from $20.25 \%$ to $39.05 \%$. This reduction gap was affected by the negative effect of salinity and sodicity on Linseed growth. Salinity- sodicity showed severe impact on the growth reduction from 20.25 to $39.05 \%$. Based on the findings, linseed (Linum usitatissimum L.) was able to grow the highest at $4 \mathrm{dSm}-1+13.5(\mathrm{mmol} \mathrm{L}-1) 1 / 2$ treatment.
\end{abstract}

Keywords: Linumusitatissimum; Saline- Sodic; Medicinal Value; Biomass Yield

\section{Introduction}

Linseed (Linum usitatissimum L.) is a cool temperate annual herb with erect stems. Although there are several utilization purposes, it is cultivated commercially for its seed, which is processed into oil and a high protein stock feed after oil extraction Sankari [1-3] and for its fibers, which are made into linen and other cloths El-Nagdy et al. [4]. In addition, linseed varieties with oils suitable for culinary use are available Hosseinian et al. [5]. Seedling establishment is generally slow and seedlings have poor competitive ability. In arid and semi-arid regions where rainfall is insufficient to leach salts out of the root zone, the salinity is a major problem which limits plant growth Khajeh-Hosseini et al. [6], since evaporation tends to exceed rainfall Kaya et al. [7]. Out of 20.2 million hectares of cultivated land in Pakistan, 6.8 million hectares are affected with some degree of salinity Anon [8]. The main approach of testing the linseed growth for salinity tolerance is growing it on the salt affected soils. Several researches on the classification of crop plants for salinity have been performed using various criteria such as reduction in plant growth
Bassil and Kaffka [9-11], water stress day index Katerji et al. [12], biochemical activities Johnson et al. [13], ion balance Alian et al. $[4,15]$, and yield reduction Natarajan et al. [16].

Linseed (Linum usitatissimum L.) is an important crop produced for natural textile fibre (linen) or oil for industrial application as well as culinary purpose. Recently the market has evolved around linseed as a functional food laden with health promoting properties further highlighting its importance and increased demand. The total world production of linseed reached approximately 2.56 million tons in the year 2014, with Canada (34 \%), the Russian Federation (15\%), and China (13\%) being the main producers (FAOSTAT, 2016). In world germplasm collections, there are 46,513 linseed/flax accessions reported (with perhaps 10,000-15,000 unique accessions), of which L. bienne (the wild progenitor of cultivated flax) is rarely represented (279 accessions only) in gene banks Diederichsen [17]. Linseed germplasm is also represented by cultivars, landraces, wild relatives and other wild ancestral species 
which breeders can exploit to improve cultivars for future climatic adaptations Heslop-Harrison and Schwarzacher [18] Diederichsen and Fu.

Further, the use of landraces for fibre flax breeding was described by Zhuchenko and Rozhmina [19]. Such studies have proven to be useful tools for efficiently preserving and using flax germplasm collections Diederichsen [17,20,21]. These primary evaluations of flax germplasm collections were followed by numerous secondary evaluations for different characters related to tolerance to biotic and abiotic stress factors Brutch $[19,22]$ with recent focus of germplasm screening on monogenic traits, such as disease resistances Rashid [23]. Some work on the effect of salinity on germination and growth of medicinal plants include Linum usitatissimum, Trigonella foenum-graecum Ashraf et al. [10, 24-30] Ricinus communis Raghavaiah [31]. It appears that little information is available regarding the effect of salinity on the growth and productivity of medicinal plants.

Lepidium sativum L., Linum usitatissimum L., Plantago ovata Forssk and Trigonella foenum-graecum L. have been evaluated and proved to be moderately salt tolerant at germination and seedling growth stage Muhammad \& Hussain [32]. Supplies of good quality water are falling short of demand for intensive irrigated agriculture in many arid and semi-arid countries due to increased pressures to produce more for the growing population as well as competition from urban, industrial and environmental sectors. Therefore, available freshwater supplies need to be used more efficiently. In addition, reliance on saline waters generated by irrigated agriculture or pumped from aquifers seems inevitable for irrigation Bouwer [33] Qadir et al. The same applies to salt-affected soils, which occur on 831.106 ha Beltra'n and Manzur [34]. Sodicity causes structural problems in soils created by physical processes such as slaking, swelling and dispersion of clay; as well as conditions that may cause surface crusting and hard setting Quirk [35].

Several major irrigation schemes throughout the world have suffered from the problems of salinity Gupta and Abrol [3638]. Generally, the worst salinity impacts occur where farming communities are relatively poor and face economic difficulties. In severe cases, salinization causes occupational or geographic shifting of the affected communities, with the male population seeking alternate off-farm income opportunities Abdel- [1,40]. As the agricultural use of salt-affected land and saline water resources increases, their sustainable use for food and feed production will become a more serious issue Suarez [41], Wichelns and Oster, 2006. In the future, sustainable agricultural systems using these resources should have good crop production with minimized adverse environmental and ecological impacts Qadir and Oster [42]. Salt-affected soils are reported to comprise 42.3 per cent of the land area of Australia, 21.0 per cent of Asia, 7.6 per cent of South America, 4.6 per cent of Europe, 3.5 per cent of Africa, 0.9 per cent of North America and 0.7 per cent of Central America.
Australia has the world's largest area under salinity which is reported equivalent to about one third of the total area of the continent. Recent estimates indicate that 6.74 million ha (CSSRI, 2006; NBSSLUP, 2006; NRSA, 2006) in India are affected by soil salinity and alkalinity. In the present scenario human use of poorquality irrigation systems is a major concern for scientists around the world. Therefore, apart from the need for proper irrigation practices a concerted effort to understand the effect of salinity on plants, development of genetically engineered crop varieties and superior tolerant cultivars are essential to combat the world's salinization problems Tester and Davenport [43].

\section{Materials and Methods}

A pot study was conducted to evaluate the salt tolerance of Linseed (Linum usitatissimum L.) as medicinal plant under different saline and sodic concentrations at green house of Land Resources Research Institute, National Agricultural Research Centre, Islamabad, Pakistan during, 2017. The soil used for the pot experiment was analysed and having 7. $0 \mathrm{pH}, 1.8 \mathrm{ECe}(\mathrm{dSm}-$ 1), 4.9 SAR (mmol L-1)1/2, 22.5 Saturation Percentage (\%), 0.33 O.M. (\%), 7.0 Available P (mg Kg-1) and 95.9 Extractable $\mathrm{K}$ (mg Kg-1). Considering the pre- sowing soil analysis the ECe (Electrical conductivity) and SAR (Sodium Absorption Ratio) was artificially developed with salts of $\mathrm{NaCl}, \mathrm{Na}_{2} \mathrm{SO}_{4}, \mathrm{CaCl}_{2}$ and $\mathrm{MgSO}_{4}$ using Quadratic Equation.10 Kg soil was used to fill each pot. 10 seeds of Linseed (Linum usitatissimum L.) as medicinal plant were sown in each pot. Fertilizer was applied @60-50-40 NPK Kg ha1. Treatments were $(4 \mathrm{dSm}-1+13.5(\mathrm{mmol} \mathrm{L}-1) 1 / 2,5 \mathrm{dSm}-1+$ 25 (mmol L-1)1/2, $5 \mathrm{dSm}-1+30$ (mmol L-1)1/2, 10dSm-1 + 25 (mmol L-1)1/2, 10dSm-1 + 25 (mmol L-1)1/2 and $10 \mathrm{dSm}-1+30$ (mmol L-1)1/2). Completely randomized deign was applied with three repeats. Data on biomass yield were collected. Collected data were statistically analysed and means were compared by LSD at 5 $\%$ Montgomery [44].

\section{Results and Discussions}

Salinity adversely reduces the overall productivity of plants including crops by inducing numerous abnormal morphological, physiological and biochemical changes that cause delayed germination, high seedling mortality, poor crop stand, stunted growth and lower yields. So Biosaline agriculture (utilization of these salt- affected lands without disturbing present condition) is an economical approach. Therefore, a pot study was designed to evaluate the salt tolerance of Linseed (Linum usitatissimum L.) at various salt concentrations. Significant difference was found among treatments on biomass yield (Table 1 ). Highest biomass yield (45.53 gpot-1) was attained by $4 \mathrm{dSm}-1+13.5$ (mmol L-1) $1 / 2$ treatment. Biomass yield was decreased as well as the toxicity of salts was increased. Lowest biomass yield (27.75 gpot-1) was produced at 10 $\mathrm{dSm}-1+30$ (mmol L-1)1/2. Germination and seedling emergence may be influenced by temperature, sowing depth and seedbed 
conditions like available moisture and salinity Couture et al. [45]; Kurt and Bozkurt [2]. Salinity leads to delayed germination and emergence, low seedling survival, irregular crop stand and lower yield due to abnormal morphological, physiological and biochemical changes Munns [15]; Muhammad and Hussain [31].

Table 1 also explored the \% decrease in biomass yield over control. $5 \mathrm{dSm}-1+25$ (mmol L-1)1/2 treatment performed better results i.e. the least reduction \% over control (20.25). Salinitysodicity showed serious effect on the growth reduction from 20.25 to39.05\%. This huge fissure was impacted by the negative effect of salinity cum sodicity on Linseed (Linum usitatissimum L.) growth. Such problems affect water and air movement, plant-available water holding capacity, root penetration, runoff, erosion and tillage and sowing operations. In addition, imbalances in plant-available nutrients in both saline and sodic soils affect plant growth Qadir and Schubert [46-50].

Table 1: Effect of various salinity and sodicity levels on biomass yield of Linseed (Linum usitatissium) as medicinal crop.

\begin{tabular}{|c|c|c|}
\hline Treatments & $\begin{array}{l}\text { Biomass Yield } \\
\text { (gpot-1) }\end{array}$ & $\begin{array}{l}\% \text { Decrease } \\
\text { Over Control }\end{array}$ \\
\hline $\begin{array}{c}\mathrm{ECe}=4 \mathrm{dSm}^{-1}+\mathrm{SAR}=13.5(\mathrm{mmol} \\
\left.\mathrm{L}^{-1}\right)^{1 / 2}\end{array}$ & $45.53 a$ & ------- \\
\hline $\begin{array}{c}\mathrm{ECe}=5 \mathrm{dSm}^{-1}+\mathrm{SAR}=25(\mathrm{mmol} \\
\left.\mathrm{L}^{-1} /\right)^{1 / 2}\end{array}$ & 36.31ab & 20.25 \\
\hline $\begin{array}{c}\mathrm{ECe}=5 \mathrm{dSm}^{-1}+\mathrm{SAR}=30(\mathrm{mmol} \\
\left.\mathrm{L}^{-1}\right)^{1 / 2}\end{array}$ & $33.60 \mathrm{bc}$ & 26.20 \\
\hline $\begin{array}{c}\mathrm{ECe}=10 \mathrm{dSm}^{-1}+\mathrm{SAR}=25(\mathrm{mmol} \\
\left.\mathrm{L}^{-1}\right)^{1 / 2}\end{array}$ & $32.29 \mathrm{c}$ & 26.88 \\
\hline $\begin{array}{c}\mathrm{ECe}=10 \mathrm{dSm}^{-1}+\mathrm{SAR}=30(\mathrm{mmol} \\
\left.\mathrm{L}^{-1}\right)^{1 / 2}\end{array}$ & $27.75 \mathrm{~d}$ & 39.05 \\
\hline LSD at $5 \%$ & 5.31 & \\
\hline
\end{tabular}

\section{Conclusion}

Based on the findings, Linseed (Linum usitatissimum L.) was able to how more salt tolerance at $4 \mathrm{dSm}-1+13.5$ (mmol L-1)1/2 treatment [51-56]. Therefore, Linseed (Linum usitatissimum L.) is suggested to be cultivated in soil salinity farmlands.

\section{References}

1. Sankari HS (2000) Linseed (Linum usitatissimum L.) cultivars and breeding lines as stem biomass producers. Journal of Agronomy and Crop Sciences 184(4): 225-231.

2. Kurt O, Bozkurt D (2006) Effect of temperature and photoperiod on seedling emergence of flax (Linum usitatissimum L.). Journal of Agronomy 5(3): 541-545.

3. Berti M, S Fischer, R Wilckens, F Hevia, B Johnson (2010) Adaptation and genotype $\times$ environment interaction of flaxseed (Linum usitatissimum L.) genotypes in South Central Chile. Chilean Journal of Agricultural Research 70: 345-356.

4. El Nagdy, GA, Nassar DMA, El Kady EA, El Yamanee GSA (2010) Response of flax plant (Linum usitatissimum L.) to treatments with mineral and bio-fertilizers from nitrogen and phosphorus. Journal of American Science 6: 207-217.
5. Hosseinian FS, GG Rowland, PR Bhirud JH Dych, Tyler RT (2004) Chemical composition and physicochemical and hydrogenation characteristics of high-palmitic acid solin (lowlinolenic acid flaxseed) oil. Journal of the American Oil Chemists' Society 81: 185-188.

6. Khajeh Hosseini M, Powell AA, Bingham IJ (2003) The interaction between salinity stress and seed vigour during germination of soybean seeds. Seed Science and Technology 31: 715-725.

7. Kaya MD, Ipek A, Ozturk A (2003) Effects of different soil salinity levels on germination and seedling growth of safflower (Carthamus tinctorius L.). Turkish Journal of Agriculture and Forestry 27:221-227.

8. Anonymous (2002) Agricultural Statistics of Pakistan. Government of Pakistan, Ministry of Food, Agriculture and Live Stock, Economic Wing, Islamabad p. 83-84.

9. Bassil ES, and SR Kaffka (2002) Response of safflower (Carthamus tinctorius $L$.) to saline soils and irrigation II. Crop response to salinity. Agricultural Water Management 54: 81-92.

10. Akhtar J, T Ul Haq, A Shahzad, M Anwar Ul Haq, M Ibrahim, N Ashraf (2003) Classification of different wheat genotypes in salt tolerance categories on the basis of biomass production. International Journal of Agriculture and Biology 5: 322-325.

11. Hakim MA, Juraimi AS, Begum M, Hanafi MM, Ismail MR, et al. (2010) Effect of salt stress on germination and early seedling growth of rice (Oryza sativa L.). African Journal of Biotechnology 9(13):1911-1918.

12. Katerji N, Van Hoorn JW, Hamdy A, Mastrorilli M (2000) Salt tolerance classification of crops according to soil salinity and to water stress day index. Agricultural Water Management 43: 99-109.

13. Johnson HE, D Broadhurst, R Goodacre, and A.R. Smith. 2003. Metabolic fingerprinting of salt-stressed tomatoes. Phytochemistry 62(6): 919928.

14. Alian A, A Altman, B Heuer (2000) Genotypic difference in salinity and water stress tolerance of fresh market tomato cultivars. Plant Science 152(1): 59-65.

15. Munns R, James RA, Läuchli A (2006) Approaches to increasing the salt tolerance of wheat and other cereals. J Exp Bot 57(5): 1025-1043.

16. Natarajan SK, Ganapathy M, Krishnakumar S, Dhanalakshmi R, Saliha BB (2005) Grouping of rice genotypes for salinity tolerance based upon grain yield and $\mathrm{Na}: \mathrm{K}$ ratio under coastal environment. Research Journal of Agriculture and Biological Sciences 1: 162-165.

17. Diederichsen A (2007) Ex-situ collections of cultivated flax (Linum usitatissimum $L$.) and other species of the genus Linum L. Genet Resour Crop Evol 54(3): 661-678.

18. Heslop Harrison JS, Schwarzacher T (2012) Genetics and genomics of crop domestication. In: Altman A, Hasegawa PM (Eds.). Plant biotechnology and agriculture: Prospects for the $21^{\text {st }}$ century. Elsevier Academic, USA p. 3-18.

19. Zhuchenko AA, Rozhmina TA (2000) Mobilizacija genetičeskich resursov l"na [Mobilization of flax genet-ic resources]. VILAR AND VNIIL, Starica pp. 224.

20. Diederichsen A, Fu YB (2008) Flax genetic diversity as the raw material for future success. In: Proceedings of the international conference on flax and other bast plants, Saskatoon, Canada pp. 270-280.

21. Diederichsen A, Kusters PM, Kessler D, Bainas Z, Gugel RK (2013) Assembling a core collection from the flax world collection maintained by Plant Gene Resources of Canada. Genetic Resources Crop Evolution 60(4): 1479-1485.

22. Brutch NB (2002) The flax genetic resources collection held at the N.I. Vavilov Institute, Russian Federation. In: Maggioni LM, Pavelek M, Van Soest LJM, Lipman E (Eds.). Flax genetic resources in Europe. IPGRI, Maccarese Rome pp. 61-65.

23. Rashid KY (2003) Principal diseases of flax. In Flax, the genus Linum, Muir AD, Westcott ND (Eds.). Taylor \& Francis, London, UK, pp. 92-123. 
24. Mutlu F, Buzcuk S (2007) Salinity induced changes of free and bound polyamine levels in sunflower (Helianthus annuus $L$.) roots differing in salt tolerance. Pak J Bot 39(4): 1097-1102.

25. Umezawa T, Shimizu K, Kato M, Ueda T (2000) Enhancement of salt tolerance in soybean with $\mathrm{NaCl}$ pretreatment. Physiol Plant 110(1): 5963.

26. Essa TA (2002) Effect of salinity stress on growth and nutrient composition of three soybean (Glycine $\max (L$.) Merrill) cultivars. Journal of Agronomy \& Crop Science 188(2): 86-93.

27. Farhoudi R, Sharifzadeh F (2006) The effect of $\mathrm{NaCl}$ priming on salt tolerance in canola (Brassica napus L.) seedlings grown under saline conditions. Indian J Crop Science 1(1-2): 74-78.

28. Gul H, Ahmad R (2007) Effect of different sowing dates on the vegetative and reproductive growth of canola (Brassica napus L.) cultivers under different salinity levels. Pak J Bot 39(4): 1161-1172.

29. Ulfat M, Athar H, Ashraf M, Akram NA, Jamil A (2007) Appraisal of physiological and biochemical selection criteria for evaluation of salt tolerance in canola (Brassica napus L.) Pak J Bot 39(5): 1593-1608.

30. Janagard MS, Tobeh A, Esmailpour B (2008) Evaluation of salinity tolerance of three canola cultivars at germination and early seedling growth stage. Journal of Food, Agriculture \& Environment 6(2): 272-275.

31. Raghavaiah CV, Lavanya C, Kumaran S, Royal TJ (2006) Screening castor (Ricinus communis) genotypes for salinity tolerance in terms of germination, growth and plant ion composition. Indian Journal of Agricultural Sciences 76(3): 196-199.

32. Muhammad Z, Hussain F (2010) Effect of $\mathrm{NaCl}$ salinity on the germination and seedling growth of some medicinal plants. Pakistan Journal of Botany 42(2): 889-897.

33. Bouwer H (2002) Integrated water management for the $21^{\text {st }}$ century: Problems and solutions. Journal of Irrigation and Drainage Engineering 28: 193-202.

34. Beltran JM, Manzur CL (2005) Overview of salinity problems in the world and FAO strategies to address the problem. In Proceedings of the International Salinity Forum, 25-27 April 2005, Riverside, CA 311-313.

35. Quirk JP (2001) The significance of the threshold and turbidity concentrations in relation to sodicity and microstructure. Australian Journal of Soil Research 39(6): 1185-1217.

36. Gupta RK, Abrol IP (2000) Salinity build-up and changes in the ricewheat system of the Indo-Gangetic Plains. Experimental Agriculture 36: 273-284.

37. Cai X, McKinney DC, Rosegrant MW (2003) Sustainability analysis for irrigation water management in the Aral Sea region. AgriculturalSystems 76(3): 1043-1066.

38. Sarraf M (2004) Assessing the Costs of Environmental Degradation in the Middle East and North Africa Countries. Environmental Strategy Notes (No. 9), Environment Department, World Bank: Washington, DC, USA.

39. Abdel Dayem S (2005) Understanding the social and economic dimensions of salinity. In Proceedings of the International Salinity Forum, 25-27 April 2005, Riverside, California, USA p. 1-4.
40. Qadir M, Noble AD, Schubert S, Thomas RJ, Arslan A (2006) Sodicityinduced land degradation and its sustainable management: Problems and prospects. Land Degradation \& Development 17(6): 661-676.

41. Suarez DL (2001) Sodic soil reclamation: Modelling and field study. Australian Journal of Soil Research 39(6): 1225-1246.

42. Qadir M, Oster JD (2004) Crop and irrigation management strategies for saline-sodic soils and waters aimed at environmentally sustainable agriculture. Science of the Total Environment 323(1-3): 1-19.

43. Tester M, Davenport R (2003) Na+ tolerance and Na+ transport in higher plants. Annals of Botany, 91(5): 503-527.

44. Montgomery DC (2001) Design and Analysis of Experiments ( $5^{\text {th }}$ Edn.). John Willey and Sons, New York, USA, p. 64-65.

45. Couture SJ, A DiTommaso, WL Asbil, AK Watson (2004) Influence of seeding depth and seedbed preparation on establishment, growth and yield of fibre flax (Linum usitatissimum L.) in Eastern Canada. Journal of Agronomy and Crop Science 190: 184-190.

46. Qadir M, Schubert S (2002) Degradation processes and nutrient constraints in sodic soils. Land Degradation \& Development 13(4): 275294.

47. Akhtar SS, Andersen MN, Naveed M, Zahir ZA, Liu F (2015) Interactive effect of biochar and plant growth-promoting bacterial endophytes on ameliorating salinity stress in maize. Functional Plant Biology. 42(8): 770-781.

48. Ashraf M, R Zafar, MY Ashraf (2003) Time-course changes in the inorganic and organic components of germinating sunflower achenes under salt $(\mathrm{NaCl})$ stress. Flora- Morphology, Distribution, Functional Ecology of Plants 198(1): 26-36.

49. Burt S (2004) Essential oils: their antibacterial properties and potential applications in foods-a review. Internat J Food Microbiol 94: 223-253.

50. (2006-2007) Central Soil Salinity Research Institute. Annual Report, Central Soil Salinity Research Institute, Karnal.

51. FAOSTAT (2016) Production of Crops: Linseed: Area Har-vested and Production (tonnes).

52. Munns R (2002) Comparative physiology of salt and water stress. Plant, Cell and Environment 25(2): 239-250.

53. (2006) National Bureau of Soil Survey and Land Use Planning. Annual Report, National Bureau of Soil Survey and Land Use Planning.

54. (2006) National Remote Sensing Agency, Annual Report, National Remote Sensing Agency, Hyderabad.

55. Raghavaiah CV, Muralidharudu Y, Royal TJJ, Ammaji P, Lavanya C, et al. (2002) Influence of salinity stress on germination and early growth of castor (Ricinus communis) genotypes. Indian Journal of Agricultural Sciences 72(10): 601-603.

56. Zhu JK (2001) Plant salt tolerance. Trends Plant Sci 6(2): 66-71. 


\section{ISSN: 2574-1241}

DOI: 10.26717/BJSTR.2018.10.001975

Muhammad Arshad Ullah. Biomed J Sci \& Tech Res

CC (i) This work is licensed under Creative

Submission Link: https://biomedres.us/submit-manuscript.php

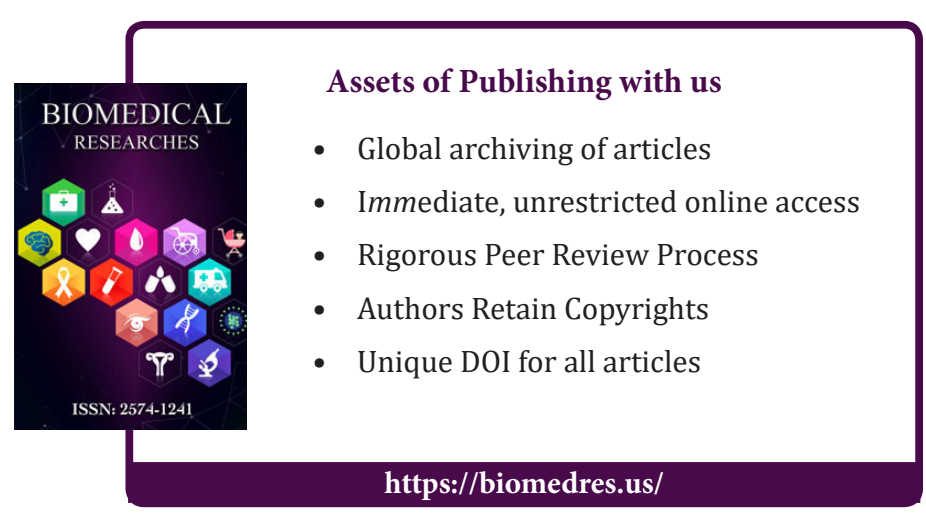

